\title{
Features of methodological principles of formation land use of defense
}

Tretiak A. doctor of economics, professor, Corresponding Member of the National Academy of Sciences of Ukraine

Melnychuk A. graduate student,

State Ecology Academy of Postgraduate Education and Management

The new economic conditions and the emergence of Ukraine as an independent and sovereign state testify to the need to form a perfect basis for land relations. At the same time, their effective regulation, in order to ensure one of the basic norms of the Constitution of Ukraine, namely the safety of life of the population for present generations and future, is to improve the methodological foundations of the formation of land use defense. The choice and direction of the study are specified and stipulated. This is due to the fact, that one of the most problematic places is the allocation of defense lands for their intended purpose and functional use within this category. In particular, it does not take into account the multifunctionality of land use, the imposition on the category of lands of defense of agricultural and forestry land use. As well as ambiguity in determining the purpose of land and formulating functional use according to the existing classification.

The object of the study is the process of forming land-use defenses. To achieve this goal, we used such research methods as systematic approach, monographic, general scientific methods of analysis and synthesis, theoretical generalization and comparison, as well as abstract-logical.

The feasibility of the distribution of defense lands by functional land use types (subtypes) substantiated during the study. A model of the methodological process of distribution of defense lands proposed, depending on the basic functions of land in society and on the defense-security, social, economic, environmental and technological public interests for establishing the regime (regulations) of land use. It recommended prioritize the types (subtypes) of land use within defense lands, in descending order, depending on the functions of the land in the development of society and the country's defense capability. 
The proposed approach to the distribution of defense lands will allow them to carry out a scientifically sound classification of land use types (subtypes) and to form appropriate regimes for the use and protection of land and other natural resources. As well as imposing restrictions and burdens, this will ensure the safety of life of the population, both for present generations and for future ones.

Keywords: land use of defense, land category, land use types, land use regime.

\section{Introduction}

Land, as a unique object in the system of social relations, to which the interests of all members of human society direct, is a universal factor in social life support, namely as:

1) the subject and the means of labor in the basic branches of production, in particular in agriculture and forestry;

2) the spatial basis of the existence of each person in all forms of his life without exception;

3) the carrier of rich natural resources;

4) territorial basis of statehood and national self-determination.

That is why all members of society are directly and indirectly involve in the system of land relations and land use. By giving these relationships a diversity of needs that intersect, complement, or, conversely, exclude one another, interests, values, orientations, and motivations [1].

This means that the system of land relations and land use is a complex category of national (including defense and security), group (territorial) and individual interests. Which may arise from the distribution and redistribution of land resources, their productive and efficient use, and the protection and rational restoration of useful consumer properties of land lost in the course of economic activity. It distinguished into an exclusive socio-economic and defense-security category because of the specificity of the earth as a unique object of common multi-purpose interests, namely based on the triple function of the earth:

1) spatial operating basis;

2) integral natural resource - sources of food and means of production;

3) bearer of social and social interests and environmental conditions of the population, in the system of public interests.

Land use efficiency needs to considered in five aspects: social, social, economic, and environmental and defense-security. Accordingly, many land interests that arise in society can divided into groups [2]:

a) interests regarding the effective mastery of the natural properties of the land resource (ecological and technological interests);

b) interests regarding commodity-monetary parameters of land ownership (socio-economic interests); 
c) interests in defense and security of land use parameters (public interests)

That is why, in the system of public interests, land use of defense must considered, in addition to social, economic and environmental, and in the fourth aspect - public, with the inclusion of defense and security.

The analysis of scientific literature suggests that the study of this problem in one way or another paid attention to the following scientists: Garage O., Dyachenko V., Romanyuk M., Lisova T., Martin A., Tretyak A. and others. However, research is generally theoretical in nature and relates to specific aspects of the right to use defense lands. More significant contributions to the study of this direction have foreign scientists, in particular: Belin J., Gagzad A., Sadegi F., Hartley K. [3, 4, 5] and others. Therefore, at this stage of reforming the Armed Forces of Ukraine, namely bringing their activities to European requirements, the issue of land use regimes has become particularly relevant and needs appropriate solutions.

Thus, the object of the study is the process of forming a land use defense to ensure the safety of life of the population.

The purpose of the work is to investigate the peculiarities of the methodological foundations of the formation of land use defense and to formulate appropriate proposals for the land management process.

\section{Research methodology}

The theoretical basis of the study was the current provisions and principles of economic theory, economics of land and nature, numerous scientific works of national and world importance on issues related to the nature of the problems that were solve in this article. Research use the following scientific methods: a systematic approach - when investigating the essence of the defense safety of life to ensure the safety of life of the population; monographic - to analyze the scientific views of scientists about the problem and the normative documents related to the object of research; general scientific methods of analysis and synthesis, theoretical generalization and comparison - while refining the conceptual and categorical apparatus, the foreign experience of the safety of life of the population has been investigated; abstract-logical - for theoretical generalizations and justification of the purpose and formation of conclusions.

\section{Results of the research and discussion}

The Constitution of Ukraine (Article 3) enshrines the norms: "A person, his life and health, honor and dignity, integrity and safety are recognized in Ukraine as the highest social value. Human rights, freedoms, and their guarantees determine the content and orientation of the state. The state is responsible to the person for its activities. Promoting and safeguarding human rights and freedoms is a major responsibility of the state" [6]. Recognizing the life and health of a person of the highest social value requires special consideration for the specific conditions of his life, in particular the use of the earth and its natural resources. Socio-economic, environmental and defense-security relations should serve firstly the interests of all 
citizens of Ukraine (national interests). They must understood by all citizens and fully supported by civil society in an open dialogue [7].

According to research [1], land interests that arise in society in the system of land use economy divided into three groups:

1) in the field of distribution and redistribution of land resources, the first group of public land interests (social) is oriented to the parameters of the size of property for different social groups and forms of land use;

2) the second economic group of public land interests in the field of distribution and redistribution of land resources is aimed at the structure of land ownership in terms of composition, combination and proposals that constitute economic forms of land use;

3 ) the third group of public land environmental interests is oriented on the parameters of the functional and economic structure of the land fund. It focuses on the scope, proportions and priorities of its distribution by the degree of economic development (mastered, poorly mastered and not mastered). Also on species and categories (arable land, hayfields, pastures, areas under construction, forestlands, shrubs, swamps, etc.) and intensity of operation and anthropogenic action. Both public and individual interests, for the most part, are equally focus on maintaining the most efficient environmental structure of the land fund organized during land management.

It is necessary to distinguish one more aspect of directions of expression of public interests and dependencies, it is defensive and safe. Here, land use allocated to an extraordinary block in the system of socio-economic and environmental relations due to the specificity of the land as a peculiar category of national interests and an exclusive kind of territorial resource.

Taking into account historical experience, current socio-economic and ecological situation in Ukraine, ethnic and cultural factors, the strategic goal of land use of defense formation is to ensure the most rational land use, comprehensive protection and creation of ecologically safe land use on this basis.

In this regard, the problem of land allocation is one of the traditionally complex and, until now, unresolved problems [8,9]. First, the problem of land allocation in terms of scientific approach must solved using the methods of discrete mathematics, methods of cluster analysis, theory of busting and other methods of mathematical statistics. Second, land allocation approaches relate to the particularities of the functions that land performs in society, the criteria chosen for land classification, which in turn cannot be absolute and uniform for all occasions. This approach is impossible even theoretically. Therefore, land allocation should base on clearly defined target criteria, parameters and attributes, the system of which determined by a specific subject area and the requirements of specific groups of land users.

However, land redistribution must made according to these needs and the interests of the people (society). After all, the earth, as a natural resource, depending on the value and availability of certain natural resources, performs the following functions [10]: 
- $\quad$ the basic basis of all existing biocenoses and the biosphere as a whole;

- $\quad$ - the main source of aesthetic beauty and wealth of the whole natural complex as a whole.

That's why, land use of defense should classified by special and other modes of use and protection of land and other natural resources, by subtypes: - land use with a low degree of ecological and economic risk; - land use with significant environmental and economic risk; - land use with increased ecological and economic risk; - land use with catastrophic degree of ecological and economic risk.

The above classification makes it possible to more fully reveal the category of ecological and economic risk in land use of defense and leads to further consideration of its peculiarities.

Use the understanding of the nature of land allocation for defense and security purposes it is possible to formulate its concept. Thus, the allocation of land for defense and security purposes is a process of land allocation taking into account the needs of the state's defense capability. In turn, it should be aimed at satisfying the public interest of the state in defense and security needs, with appropriate functional zoning of the use and protection of land and other natural resources (by land use subtypes), taking into account various degrees of ecological and economic risk. The implementation of a scientifically grounded distribution of land by types (subtypes) of land use, purpose and functional use is one of the functions of the state to implement land policy in the field of defense.

Thus, the essence of land allocation lies in balancing contradictions in the needs of the state's land for defense and security purposes and the availability (possibility of allocating zones of subtypes of land use) of land and other natural resources of an appropriate amount and regime of land use.

Therefore, the allocation of land by types (subtypes) of land use within the category of defense lands should base on ecological and economic characteristics and methods of use and protection of land and other natural resources. Based on the functions of the earth, which it performs in the defense of the country, it is advisable to distinguish:

1) lands used as the territorial basis of the defense sphere;

2) land with special use regime, including nature protection;

3) land used as a primary means of production.

The authors' suggestions for improving the allocation of land by use function show in Fig. 1. 


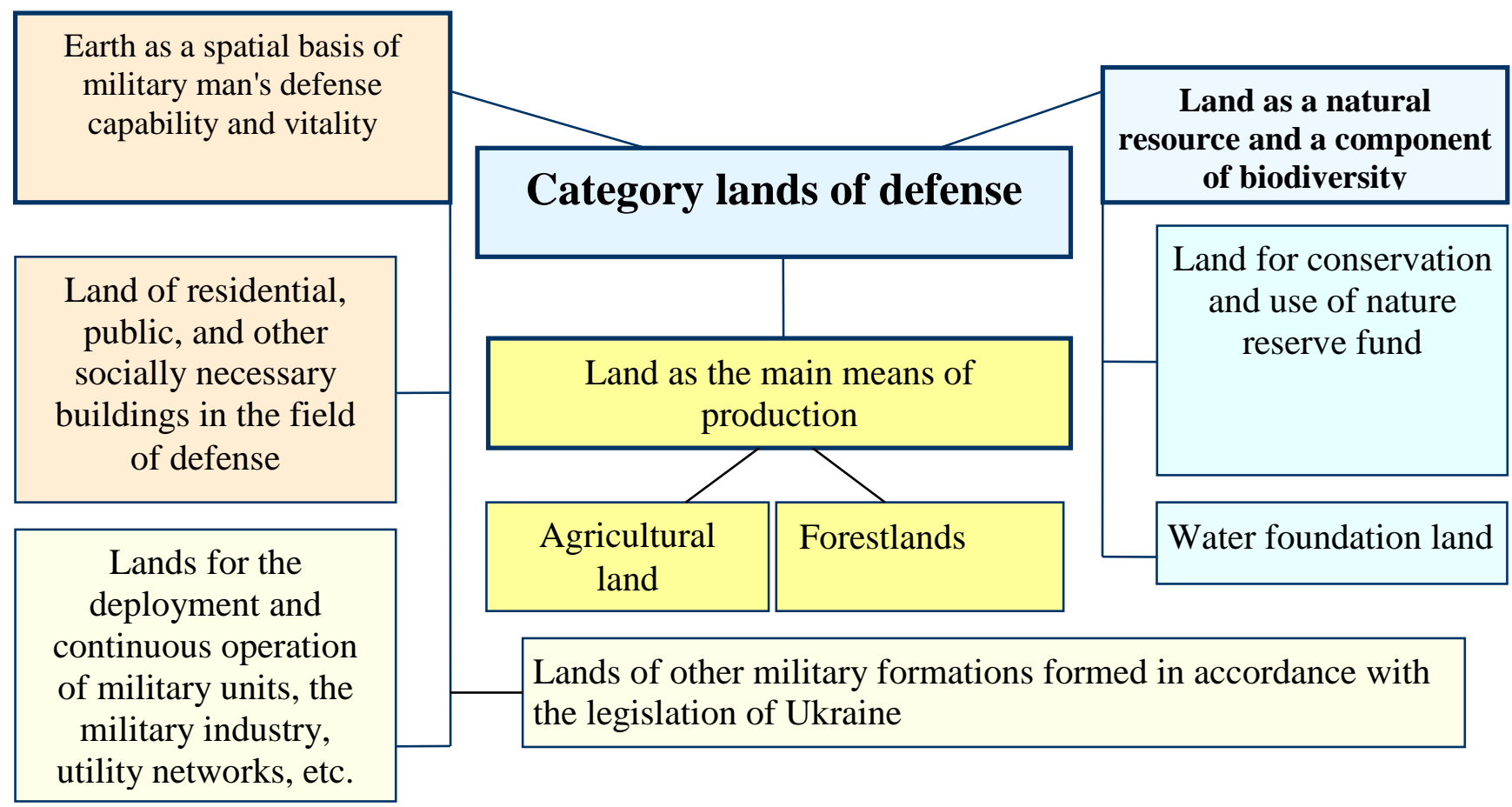

Figure 1. Logical and semantic scheme of the distribution of defense lands by functional types (subtypes) of land use.

The foregoing causes the change of the methodological process of land use distribution within the category of defense lands (Fig. 2). 


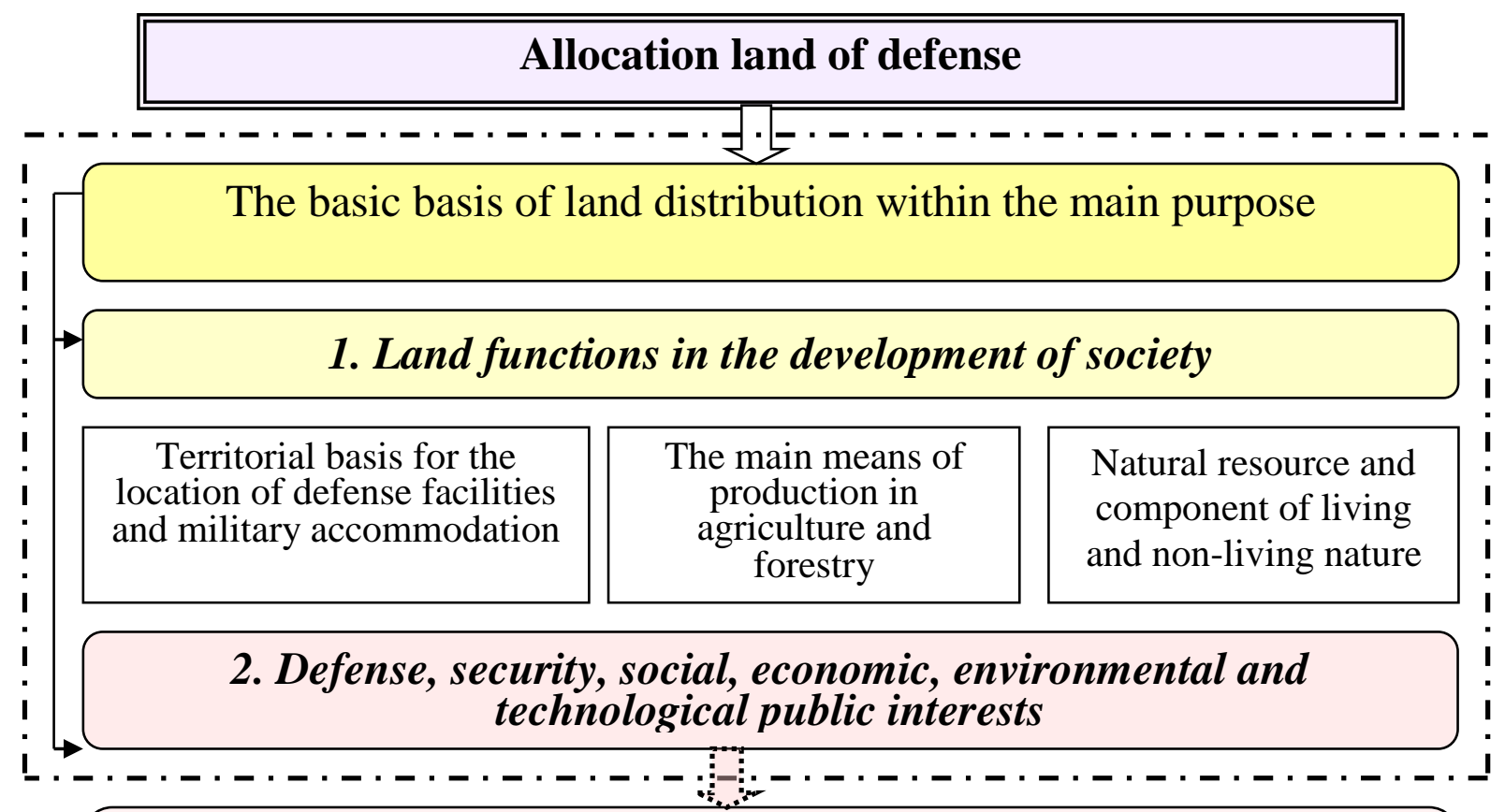

Divide of land within the category and types (subtypes) of land use depending on the functional use of land and other natural resources

Divide by land use łypes (subtypes) (land zoning)

Divide land according to purpose by type of use
Divide by purpose and functional use
Divide land depending on the legal regime of land use
A) by land use forms;
(5) under the legal regime, including by the degree of ecological and
econic risk.

Figure 2. Logical and semantic model of the methodological process of allocation of defense lands by types (subtypes), target and functional use (author's development using the source: [8]).

Thus, the model of the methodological process of land allocation within the category of defense in Ukraine should base on the functions of land that it performs in the development of society. Land allocation must base on land use types (subtypes) depending on defense, security, social, economic and environmental public interests, taking into account land use regimes and other natural resources. 
In practice, the problem is that the land may belong to several categories of land at the same time. For example, when defense lands include forest and water resources, agricultural lands, etc. (a very common situation). The current land legislation does not regulate the relationship between the regimes of different categories of land, except in cases of land taxation by land tax. For defense lands, the conflicts that arise between different legal regimes pose a serious problem.

On this basis, we consider it necessary to recognize the possibility of belonging to one land plot of defense at the same time to several types (subtypes) of land use. In doing so, land use rules (regulations) should establish using institutions that restrict land use and other natural resources and encumber land rights. First of all, this is possible by prioritizing land use types (subtypes) over others.

It seems, that the priorities of land use types (subtypes) within the defense lands should arrange as follows (in descending order):

- specially protected territories (land parcels of military property: buildings, structures, transmissions, all types of weapons, military and other equipment, ammunition, fuel and lubricants, food, technical, airfield equipment, etc.);

- protected areas (land plots of nature, historical, cultural, recreational use);

- land areas of natural ecological systems (forest lands, wetlands, wetlands, natural steppe areas);

- agricultural land;

- land for recreational use;

- other lands (used for residential and public development, non-agricultural lands within defense lands, etc.).

Conclusions. The authors propose a scheme of the distribution of defense lands by functional types (subtypes) of land use. Its essence lies in the fact that within the category of defense lands, their distribution by land functions is carried out: the territorial basis of the location of defense objects and places of residence of the military; the main means of production for the production of agricultural products and forestry; natural resource and pantry of wild and non-living nature in protected and other areas. Subsequently, the types (subtypes) of land use are determined 
depending on the defense-security, social, economic, environmental and technological public interests for establishing the regime (regulations) of land use.

\section{References}

1. Tretiak, A. M. (2012). Ekolohiia zemlekorystuvannia: teoretykometodolohichni osnovy formuvannia ta administruvannia. Kherson: Hrin D. S., 440.

2. Tretiak, A. M. (2004). Ekonomika zemlekorystuvannia ta zemlevporiadkuvannia. Kyiv: TOV TsZRU, 542.

3. Sadeghi F., \& Haghzad A. (2015). Application of passive defense principles and approaches in urban planning with emphasizing land use (Case Study Ramsar). Research Journal of Fisheries and Hydrobiology, 10(9): 34-39. Available at:: https://pdfs.semanticscholar.org/2e03/72e4313e9dfc795f766fc67507015da998ea.pdf? _ga=2.78380637.859391505.1582017794-1114454246.1581411439.

4. Hartley, K., Belin J. (2019). The Economics of the Global Defence Industry. Routledge Studies in Defence and Peace Economics, 616.

5. Abazarlou S. (2014). Establishing the Passive Defense Rules for the use zonings in master Plan: A Sustainable Development Approach. Conference: international congress on structure architecture \& urban development, At Iran,tabriz. Available at: https://www.researchgate.net/publication/269692162_Establishing_the_Passive_Defense_Rules_for_the_use_zonings_in_master_Plan_A_Sustainable_D evelopment_Approach.

6. The Verkhovna Rada of Ukraine (1996), The Law of Ukraine "Constitution of Ukraine". Available at: http://zakon2.rada.gov.ua/laws/show/254\%D0\%BA/96\%D0\%B2\%D1\%80 (Accessed: 18.01.2020).

7. Kovaliv O. (2016). Zvershennia zemelnoi reformy v Ukraini: nova paradyhma. Kyiv: DIA, 416.

8. Lobunko, A.V. (2015). Evoliutsiia rozvytku podilu zemel za yikh katehoriiamy yak osnovnym tsilovym pryznachenniam. Zemlevporiadnyi visnyk.[The evolution of the land division by its category as the main designated purpose]. Land Management Journal, no 11, pp. 17-22. 
9. Lobunko, A.V. (2016). Podil zemel za osnovnym tsilovym pryznachenniam yak funktsiia upravlinnia zemlekorystuvanniam v Ukraini . Zemleustrii, kadastr i monitorynh zemel.[The division of the land by its main designated purpose as a function of the land-use management in Ukraine] Land management, cadastre and land monitoring, no 1-2, pp 165-171.

10. Lobunko, A.V. (2018). The ecological and economic bases of land distribution by their categories as the main target: Abstract of Ph.D. dissertation, National University of Life and Environmental Sciences of Ukraine. Kyiv, Ukraine, 256.

Третяк А. Н., Мельничук А. Ю.

МЕТОДОЛОГИЧЕСКИЕ ОСНОВЫ

ФОРМИРОВАНИЯ ЗЕМЛЕПОЛЬЗОВАНИЯ ОБОРОНЫ

Аннотация. Новые условия хозяйствования и становления Украины как независимого и суверенного государства, свидетельствуют о необходимости формирования совершенной основы земельных отномений. При этом эффективным их регулированием, для обеспечения одной из основных норм Конституции Украины, а именно безопасности жизнедеятельности населения для нынешних поколений $и$ будущих, является совершенствование методологических основ формирования землепользования обороны. Этим и обусловлен выбор направления исследования. Это связано с тем, что одним из самых проблемных мест является распределение земель обороны по целевому назначению и функииональным использованием в пределах этой категории. В частности, не учета многофункциональности использования земель, наложения на категорию земель оборонь сельскохозяйственного $и$ лесохозяйственного землепользования. А также неоднозначность определения целевого назначения земельных участков и формулировки функиионального использования по существвющей классификащии.

Объектом исследования является прочесс формирования землепользования обороны. Для достижения иели использовались такие 
методы исследования, как: системный подход, монографический, общенаучные методы анализа и синтеза, теоретического обобщения и сравнения, а также абстрактно-логический.

В ходе исследования обоснована цуелесообразность распределения земель обороныл по функциональным типам (подтипами) землепользования. Предложена модель методологического прочесса распределения земель обороны в зависимости от основных функций земли в обществе и от обороннобезопасных, соцуиальных, экономических, экологических и технологических общественных интересов для установления режима (регламентов) землепользования. Приоритеть типов (подтипов) землепользования в пределах земель оборонь рекомендуется расположить в порядке убывания, в зависимости от функций земли в развитии общества и обороноспособности страны.

Предложенный подход к распределению земель обороны позволит осущуествить научно обоснованную их классификацуию по типам (подтипами) землепользования и сформировать соответствующие режимы использования и охраны земель и других природных ресурсов. А также установить ограничения и обременения, благодаря этому обеспечится безопасность жизнедеятельности населения, как для нынешних поколений, так и для будущฺхх.

Ключевые слова: землепользование обороны, категории земель, типь землепользования, режим землепользования.

$$
* * *
$$

Третяк А.М., Мельничук А.Ю.

Особливості методологічних засад формування землекористування оборони

Анотація. Новітні умови господарювання та становлення Украӥни як незалежної та суверенної держави, свідчать про потребу формування досконалої основи земельних відносин. При цзьому ефективним ӥх регулюванням, для забезпечення однієї із основних норм Конституції України, а саме безпеки життєдіяльності населення для теперішніх поколінь і майбутніх, 
є удосконалення методологічних засад формування землекористування оборони. Зазначеним й обумовлено вибір напряму дослідження. Це пов'язано з тим, щуо одним з найбільи проблемних місцьь є розподіл земель оборони за цุільовим призначення та функціональним використанням в межах цієї категорії. Зокрема не врахування багатофункиіональності використання земель, накладання на категорію земель оборони сільськогосподарського та лісогосподарського землекористування. А також неоднозначність визначення цุільового призначення земельних ділянок та формулювання функціонального використання за існуючою класифікаџією.

Об’єктом дослідження $є$ процес формування землекористування оборони. Для досягнення мети використовувалися такі методи дослідження, як: системний підхід, монографічний, загальнонаукові методи аналізу та синтезу, теоретичного узагальнення та порівняння, а також абстрактнологічний.

В ході дослідження обтрунтовано доцільність розподілу земель оборони за функціональними типами (підтипами) землекористування. Запропоновано модель методологічного процесу розподілу земель оборони залежно від основних функиій землі у суспільстві та від оборонно-безпекових, соціальних, економічних, екологічних та технологічних суспільних інтересів для встановлення режиму (регламентів) землекористування. Пріоритети типів (підтипів) землекористування в межах земель оборони рекомендовано розташувати в порядку зменшення, залежно від функцій землі в розвитку суспільства та обороноздатності краӥни.

Запропонований підхід до розподілу земель оборони дозволить здійснити науково-обгрунтовану їх класифікацію за типами (підтипами) землекористування і сформувати відповідні режими використання й охорони земель та інших природних ресурсів. А також встановити обмеження $i$ обтяження, завдяки ияьому забезпечиться безпека життєдіяльності населення, як для теперішніх поколінь, так, і для майбутніх.

Ключові слова: Землекористування оборони, категорї земель, типи землекористування, режим землекористування. 
